\title{
The probiotic potential of lactic acid bacteria (LAB) isolated from naniura (a traditional Batak food)
}

\author{
Mato Hang* \\ Ministry of Health, Malaysia
}

\begin{abstract}
Naniura is a Batak traditional food made from pickled goldfish. Goldfish is a freshwater fish that is consumed by a large number of people and has a high nutritional value, allowing it to be processed into fermented products. The purpose of this study was to assess the potential of lactic acid bacteria $(L A B)$ as a source of probiotics derived from naniura and to gain a better understanding of the characteristics of LAB found in naniura. The steps of this research included acidification, the preparation of naniura, the isolation of LAB using MRS media, and the determination of biochemical characteristics using Gram staining, catalase testing, and the type of fermentation. The findings of this study indicate that $L A B$ isolated from Naniura, a Batak traditional food, has the potential as a source of probiotics that are beneficial to health and inhibit the growth of pathogenic microbes. The potential of $L A B$ as a source of probiotics isolated from naniura with several test methods is able to inhibit the growth of pathogenic bacteria types Eschericia coli, Salmonella thypi and Staphylococcus aereus, besides that LAB also has strong antioxidant activity and has the potential to reduce blood glucose by inhibiting the activity of the glucosidase enzyme. The characteristics of LAB isolates in naniura were gram positive, catalase test showed negative results, and the type of fermentation was heterofermentative.
\end{abstract}

Article History

Received 3 January , 2021

Accepted 24 June , 2021

Keyword

Fermentation, Lactic acid bacteria, Naniura, Probiotic.

\section{Introduction}

Naniura is one of the traditional Indonesian food typical of Batak, North Sumatra. Naniura traditional food is made from pickled goldfish. Goldfish is a popular freshwater fish that is high in nutrition but easily damaged, resulting in it being processed into a fermented product. Naniura is unique among fermented fish products in that it incorporates a variety of spices. Spices such as garlic, onion, ginger, turmeric, kencur, cayenne pepper, candlenut, , kecombrang, and other spices are used in the manufacture of naniura. The addition of spices to this naniura food enhances the product's appearance, smell, and taste. The processing of naniura does not involve cooking, but rather acidification. The goldfish are soaked in an acid solution of lime for several hours to create naniura.

Acidification is a type of processing that involves the use of an acid solution to preserve food. The types of acids that are often used in the manufacture of naniura are oranges, limes, kaffir limes, and kaffir limes. Acid can be used to eliminate the fishy odor from fish. The acidification process lowers the $\mathrm{pH}$ of the product to prevent spoilage bacteria from growing. Along with preserving fish, using acid softens the meat because the acid initiates the hydrolysis process in the protein, softening the fish meat. The acid soaking process used in the manufacture of naniura results in dense and somewhat soft fish meat 
(1). The acidification process causes a decrease in the $\mathrm{pH}$ of the product so that it can inhibit the growth of spoilage bacteria. Fish fermentation utilizes microorganisms such as lactic acid bacteria which will grow spontaneously during the fermentation process.

LAB that is commonly found in freshwater fish, such as Lactobacillus $s p$ and Streptococcus sp (2). Because LAB, like Lactobacillus, is a probiotic-bacteria, it is extremely beneficial for health, particularly digestive tract health, and inhibits the growth of pathogenic microbes. Traditional Asian fermented foods are an excellent source of probiotics. As a result, this study will assess the potential of $L A B$ as a source of probiotics derived from naniura, as well as the characteristics of $L A B$ found in traditional naniura foods.

\section{Materials and Methods}

\subsection{Materials}

The materials used in the making of naniura and testing the potential for probiotics in naniura include Fresh Goldfish, tamarind, salt, shallots, garlic, andaliman, candlenut, cayenne pepper, red chili, peanuts, turmeric, water, de Man Rogosa Sharpe (MRS) broth, MRS agar, DPPH solution (1,1-diphenyl-2 picryhydrazil) with a concentration of $200 \mu \mathrm{g} / \mathrm{mL}$, $20 \mathrm{I}$-glucosidase (0.5 units/ml) and 120 I $0.1 \mathrm{M}$ phosphate buffer $\mathrm{pH} 6.8$.

\subsection{Research Procedure \\ 2.2.1 Making Naniura}

In the making of naniura, fresh goldfish, tamarind, and additional spices (salt, shallots, garlic, andaliman, candlenut, cayenne pepper, red chili, groundnut and turmeric) were used. The fish was then prepared by butterfly cutting it. After that, the fish were cleaned. The next stage was to prepare tamarind juice by cutting $110 \mathrm{ml}$ of tamarind and then squeezing and filtering it. Following that, the remaining ingredients were mashed. The fish was then soaked for 5 hours in tamarind juice and then soaked in spices that have been mashed until evenly distributed (3). According to previous research, the best treatment for naniura was soaking in tamarind juice for 5 hours and soaking the spices for 4 hours with a pH value of 4.1.

\subsubsection{LAB Isolation from Naniura}

Lactic acid bacteria from naniura were isolated using specific growth media, namely de Man Rogosa Sharpe (MRS) broth and MRS agar. As much as $1 \mathrm{~g}$ of naniura fish meat was dissolved into the media. Then vortex until homogeneous and then incubated at $37^{\circ} \mathrm{C}$ for 24 hours under anaerobic conditions so that the solution becomes cloudy which indicates LAB has grown. This process is called the enrichment process. After incubation, graded dilutions were carried out. A total of $0.1 \mathrm{~mL}$ of $L A B$ culture was mixed with $0.9 \mathrm{~mL}$ of sterile MRS broth in a $1.5 \mathrm{~mL}$ microtube and homogenized by inverting. This is a 10-1 dilution. The dilution is continued up to $10-7$. In this final dilution, $0.1 \mathrm{~mL}$ of LAB culture was spread onto the MRS agar surface using a spreader and incubated for up to 48 hours at $37^{\circ} \mathrm{C}(4)$. 


\subsubsection{Biochemical Characteristics}

Six LAB colonies were randomly chosen, and the microbial culture was streaked into MRS medium and incubated at $37^{\circ} \mathrm{C}$ for 48 hours. The isolates were then sequentially coded beginning with BN1, BN2, BN3, BN4, BN5, and BN6. Additionally, the catalase test, Gram stain, and fermentation method were used to determine the biochemical characteristics of $\operatorname{LAB}(5)$.

\subsubsection{Antioxidant Activity Testing}

Testing of antioxidant activity was carried out by making a solution of DPPH (1,1diphenyl-2 picryhydrazil) with a concentration of $200 \mu \mathrm{g} / \mathrm{mL}$ first. A total of $5 \mathrm{mg}$ of DPPH was weighed, put into a $25 \mathrm{ml}$ volumetric flask and the volume was filled with methanol to the mark line. After that, a blank solution with a concentration of $40 \mathrm{~g} / \mathrm{ml}$ was made by pipetting $5 \mathrm{ml}$ of DPPH solution, then put into a $25 \mathrm{ml}$ volumetric flask, adding methanol to the mark line. Then the maximum absorption wavelength was measured by means of DPPH solution with a concentration of $40 \mathrm{~g} / \mathrm{ml}$ transferred into a cuvette and placed into a spectrophotometer. The absorbance value uses a wavelength of 400 to $800 \mathrm{~nm}$. Then, $0.0625 \mathrm{ml}$ was taken; $0.125 \mathrm{ml} ; 0.250 \mathrm{ml}$; and $0.500 \mathrm{ml}$ of the mother liquor of the LAB test sample using a micro pipette into a $10 \mathrm{ml}$ volumetric flask. Add $2 \mathrm{ml}$ of DPPH (concentration $200 \mathrm{~g} / \mathrm{ml}$ ) into each volumetric flask. Added methanol until the marking line. Vortex and incubate for 30 minutes. Centrifuged at $5000 \mathrm{rpm}$ for 15 minutes and then the supernatant was taken. The absorbance was measured using a UV-Vis spectrophotometer at a wavelength of $516 \mathrm{~nm}$. Antioxidant activity was measured as the decrease in absorbance of the DPPH solution after the addition of Lactic Acid Bacteria (6).

\subsubsection{Testing of a-glucosidase, Enzyme Inhibitory Activity (7)}

This test used $20 \mu \mathrm{l} \alpha$-glucosidase $(0.5$ units $/ \mathrm{ml})$ and $120 \mu \mathrm{l} 0.1 \mathrm{M}$ phosphate buffer $\mathrm{pH}$ 6.8. As a substrate, $5 \mathrm{mM} p$-nitrophenyl- $\alpha$-Dglucopyranoside ( $\mathrm{N}-\mathrm{NPG}$ ) was used in the same buffer. A total of $10 \mu \mathrm{l}$ samples were dissolved in DMSO with various concentrations, mixed with enzyme solution in a 96-well microplate and incubated at $37^{\circ} \mathrm{C}$ for 15 minutes. During preparation and testing, enzymes should be kept at a temperature below $2-8^{\circ} \mathrm{C}$. Then $20 \mu \mathrm{l}$ of substrate solution was added and incubated again at $37^{\circ} \mathrm{C}$ for 15 minutes. The enzymatic reaction was stopped by the addition of $80 \mu \mathrm{l}$ of $0.2 \mathrm{M}$ sodium carbonate. The test was carried out in triplicate. Samples were measured using a microplate reader at $405 \mathrm{~nm}$. The enzyme inhibitory effect is calculated by the formula:

$$
\% \text { Inhibition }=\frac{[(\text { A control }- \text { A sample })]}{[\text { A control }]} \times 100 \%
$$

The linear regression equation between the sample and the inhibitory activity obtained was used in determining the $\mathrm{IC}_{50}$ number. The inhibitory activity of the glucosidase enzyme with an inhibitor concentration of $50 \%$ is called $I C_{50}$. 


\section{Results and Discussion}

\subsection{Naniura}

Naniura is a Batak traditional food made from raw carp/goldfish materials that can be consumed raw. Naniura is prepared by soaking goldfish in orange or tamarind juice for a few hours until the fish becomes soft and ready to eat. The immersion time for naniura processing with an acid solution and the addition of spices varies between 3 and 9 hours (8). Naniura, which is made from carp raw materials, is generally consumed as a protein source and is one of the most consumed types of freshwater fish. In addition, the use of several spices such as shallots, garlic, ginger, turmeric, and galangal can give a distinctive taste and aroma to naniura and can function as an antimicrobial. The processing of naniura using an acid solution allows the growth of lactic acid bacteria (LAB) such as Lactobacillus and Streptococcus as a source of probiotics and can play a role in inhibiting the growth of pathogenic microbes. Lactobacillus has benefits for human health and can inhibit the growth of pathogenic bacteria such as Salmonella, Shigella, and Helicobacter (5).

\subsection{Fish Processing with Acidification and Fermentation}

Fish is an animal protein source that contains a variety of nutrients, including protein, fat, and several vitamins. However, because fish freshness degrades rapidly due to the activity of microorganisms, particularly bacteria, additional measures to extend the shelf life of fish must be taken. Acidification and fermentation are two methods for processing fish. Acidification plays a critical role in fish processing, specifically as an antimicrobial. Acid conditions in foods affect not only the $\mathrm{pH}$, but also the activity of microorganisms. Foods that have a low $\mathrm{pH}(<4.5)$ generally cannot be grown by pathogenic bacteria, because they are relatively more resistant during storage than foods that have a neutral or close to neutral $\mathrm{pH}$ (9). The addition of acid in fish processing also causes the decomposition or breakdown of protein polymers into simpler forms so that they become easier to digest (10).

Fermentation is one way of processing and preserving preservatives. Generally, in fermented fish products, there is a lactic acid fermentation process. Fish fermentation is fermentation with a salt solution or with the addition of crystal salt which aims to inhibit the growth of destructive microorganisms that make conditions suitable for the growth of lactic acid bacteria that ferment fish so as to form a more delicious flavor (9).

\subsection{Biochemical Characteristics of Lactic Acid Bacteria}

The biochemical characteristics determined included Gram staining, catalase test and type of fermentation. The results of the analysis of biochemical characteristics are shown in Table 1. 
Table 1. Biochemical Characteristics of LAB isolated from Naniura

\begin{tabular}{lccc} 
BAL Isolate & \multicolumn{3}{c}{ Biochemical Characteristics } \\
\cline { 2 - 4 } & Gram Staining & $\begin{array}{c}\text { Type of } \\
\text { Fermentation }\end{array}$ & Catalase Test \\
\hline BN1 & Positive & Heterofermetative & Negative \\
BN2 & Positive & Heterofermetative & Negative \\
BN3 & Positive & Heterofermetative & Negative \\
BN4 & Positive & Heterofermetative & Negative \\
BN5 & Positive & Heterofermetative & Negative \\
BN6 & Positive & Heterofermetative & Negative \\
\hline
\end{tabular}

Table 1 shows that the characteristics of LAB isolates were Gram positive, heterofermentative and catalase negative (5). In the study of Syah et al (2017) regarding the isolation and identification of LAB isolated from Dangke which is a traditional cheese from Enrekang, South Sulawesi, they reported that the characteristics of LAB isolated from dangke were Gram positive, catalase negative and heterofermentative type of fermentation. Heterofermentative type of Lactic Acid Bacteria differs from homofermentative by looking at the fermentation products produced and the presence or absence of the main enzyme in glycolysis (aldolase enzyme). Heterofermentative fermenting bacteria cannot break down fructose bisphosphate into triose bisphosphate because they do not have aldolase enzyme. Heterofermentative bacteria oxidize 6phosphate glucose to pentose phosphate and with the help of the enzyme phosphoketolase will reduce it to triose phosphate (11). ATP is produced by LAB through carbohydrate fermentation. Two main lines pathway metabolism of hexoses is the pathway glycolytic (Embden-Meyerhof pathway) with lactic acid as the main end products (metabolism homofermentatif) and track fosfoketolase the main end products consisting of acetic acid, propionic acid, $\mathrm{CO}_{2}$,ethanol and lactic acid (12).

\subsection{The Results of Testing the Potential of LAB Probiotics on Naniura}

Based on the research of Aloysius et al. (2019) regarding testing the antimicrobial activity of $L A B$ against pathogenic bacteria using the disc diffusion method, it was found that 4 isolates from 6 LAB isolates isolated from naniura were able to inhibit the growth of pathogenic bacteria such as Staphylococcus aereus, Eschericia coli, and Salmonella thypi. In addition, research on the potential of probiotic naniura as an antibacterial was also carried out by Haro et al. (2020), the method used was agar diffusion and the results showed that the Lactobacillus strain isolated from naniura had good antibacterial activity against Salmonella typhi bacteria. Then testing on antioxidant activity using the DPPH method of probiotics contained in dengke naniura by Angelina (2019) found that the LAB probiotics of the Lactobacillus genus have strong antioxidant activity. The results of this study showed that the $I C_{50}$ values of $L A B$ isolated from meat and seasoning with dengke naniura were $0.342 \mathrm{ml}$ and $0.273 \mathrm{ml}(13)$. As for other studies regarding the inhibitory activity of the $\alpha-$ glucosidase enzyme by Hutahean et al. (2019) showed that LAB isolates isolated from dengke naniura had the potential to lower blood glucose by inhibiting the activity of the $\alpha$ glucosidase enzyme. 


\subsection{Factors Affecting Naniura Quality}

The quality of naniura is strongly influenced by the processing process, which consists of two important points, namely the use of acid and the duration of soaking the spices. This is in accordance with the principle of making naniura, which is soaking the fish with acid and special spices until the fish meat is softened. Acidification in food processing has often been done and is better known as marinating. This processing is one way to inhibit the growth of certain bacteria (8). In the manufacture of naniura used a type of acid in the form of orange juice. Apart from oranges, other types of oranges can also be used, where this can affect the quality characteristics of naniura. The content of compounds in the form of essential oils, citric acid, flavonoids in each type of orange is certainly different so that the ability of antibacterial and antifungal activity is also different. When compared to lime and lemon, the choice of jungga orange in making naniura is mostly done for several reasons, namely having a distinctive aroma because it is rich in citric acid and ascorbic acid. Likewise with the quality of the texture of naniura, it will significantly affect the use of different types of acid. The lower the $\mathrm{pH}$ of the acid used, the softer the texture of the naniura, this is due to acid denaturation (14). In addition, the formation of naniura texture is also influenced by the immersion time factor. The longer the acid soaking time for naniura, the higher the degree of acidity produced so that it will make the texture of the naniura meat softer, as well as the optimal absorption of spices, and on the other hand the addition of acid will reduce the growth of certain bacteria.

\section{Conclusions}

The potential of LAB as a source of probiotics isolated from naniura with several test methods is able to inhibit the growth of pathogenic bacteria types Eschericia coli, Salmonella thypi and Staphylococcus aereus, besides that LAB also has strong antioxidant activity and has the potential to reduce blood glucose by inhibiting the activity of the enzyme glucosidase. The characteristics of LAB isolates in naniura were gram positive, catalase test showed negative results, and the type of fermentation was heterofermentative.

\section{Author Contributions}

Mato Hang conceived and designed the experiments, performed the experiments, analyzed the data, contributed reagents/materials/analysis tools and wrote the paper.

\section{References}

1. Abelti AL. Microbiological and chemical changes of Nile Tilapia (Oreochromis niloticus L.) fillet during ice storage: effect of age and sex. Adv J Food Sci Technol. 2013;5(10):1260-5.

2. Nasution MHB, Ramadhani S, Fachrial E. Isolation, Characterization and Antibacterial Activities of Lactic Acid Bacteria Isolated From Batak's Special Food" Dali Ni Horbo". J Natur Indones. 2020;18(1):1-11.

3. Irianto $\mathrm{HE}$, Irianto G. Traditional fermented fish products in Indonesia. Rep 26th Sess Asia Pacific Fish Commision-FAO Beijing. 1998;24-30.

4. Hernandez D, Cardell E, Zarate V. Antimicrobial activity of lactic acid bacteria isolated from Tenerife cheese: initial characterization of plantaricin TF711, a bacteriocin-like substance produced by Lactobacillus plantarum TF711. J Appl Microbiol. 
2005;99(1):77-84.

5. Larsen AG, Vogensen FK, Josephsen J. Antimicrobial activity of lactic acid bacteria isolated from sour doughs: purification and characterization of bavaricin $A, a$ bacteriocin produced by Lactobacillus bavaricus MI401. J Appl Bacteriol. 1993;75(2):113-22.

6. Antolovich M, Prenzler PD, Patsalides E, McDonald S, Robards K. Methods for testing antioxidant activity. Analyst. 2002;127(1):183-98.

7. Andi Josep Nicolas Hutahaean, Jansen Silalahi, Dwi Suryanto and DS. Characterisation of Lactic Acid Bacteria from Dengke Naniura of Common Carp ( Cyprinus carpio) with $\alpha$-Glucosidase Inhibitory Activity. J Med Sci. 2019;7(22):3794-8.

8. Hutahaean AJN, Silalahi J, Suryanto D, Satria D. Characterisation of Lactic Acid Bacteria from Dengke Naniura of Common Carp (Cyprinus carpio) with $\alpha$-Glucosidase Inhibitory Activity. Open access Maced J Med Sci. 2019;7(22):3794.

9. Banwart G. Basic food microbiology. Springer Science \& Business Media; 2012.

10. Manik M, Kaban J, Silalahi J, Ginting M. Proximate and Amino Acid Composition of DengkeNaniura Prepared from Carp (Cyprinuscarpio) of Lake Toba Indonesia. In: Journal of Physics: Conference Series. IOP Publishing; 2019. p. 12013.

11. Astuti MP. Isolation, Characterization, and Identification Lactic Acid Bacteria from Chicken Waste Faeces that Potential as Probiotics. Int J Sci Res Publ. 2016;6(5):180.

12. Papagianni M. Metabolic engineering of lactic acid bacteria for the production of industrially important compounds. Comput Struct Biotechnol J. 2014;3(4):1-8.

13. Utama GL, Meliana S, Djali M, Yuliana T, Balia RL. Probiotic candidates yeast isolated from dangke-Indonesian traditional fermented buffalo milk. Acta Univ Agric Silv Mendelianae Brun. 2019;67:179-87.

14. Hutapea CN, Leksono T, Sari NI. The Effect of Different Kind of Citrus on The Quality of Jelawat Fish (Leptobarbus hoevenii) NANIURA. Berk Perikan Terubuk. 2019;47(2):165. 